\title{
Konsep Otoritas Alkitab di Hadapan Fakta Kesalahan Tekstual: Sebuah Diskusi Teologis
}

\author{
Yudi Jatmiko* \\ *Mahasiswa Program Studi Magister Teologi, STT SAAT, Jl. Bukit Hermon No 1, Malang, Jawa Timur. \\ Email: yudi3036@yahoo.com
}

\begin{abstract}
Abstrak: Studi kritik tekstual Alkitab menunjukkan bahwa berbagai salinan Alkitab, PL dan PB, memiliki banyak kesalahan tekstual. Masalah yang muncul ialah di hadapan fakta berbagai kesalahan tekstual yang ada, masihkah Alkitab memiliki otoritas? Para oponen menilai jelas tidak karena fakta kesalahan tekstual menimbulkan problematika yang serius berkaitan dengan ketidakpastian makna teks. Para proponen memiliki penilaian sebaliknya. Melalui diskusi teologis yang dilakukan, penulis mendapati bahwa terlepas dari berbagai kesalahan tekstual, Alkitab tetap memiliki kepastian makna teks. Ini dikarenakan bahwa perubahan teks tidak berdampak signifikan pada makna teks, jumlah varian yang banyak memungkinkan adanya ketersalingan dalam verifikasi makna, dan ketiadaan kemungkinan konspirasi menunjukkan adanya nilai dan rujukan historis di dalam teks. Kepastian makna teks ini memiliki implikasi kepastian otoritas dalam Alkitab. Akhirnya, penulis menyimpulkan bahwa kesalahan tekstual dalam Alkitab tidak meniadakan otoritas Alkitab.
\end{abstract}

Kata-kata Kunci: Otoritas Alkitab, Kesalahan Tekstual, Kritik Tekstual, Kepastian Makna Teks

Abstract: The field of Textual Criticism of the Bible has highlighted that various OT and NT manuscripts contain textual errors in the original apographs. These errors indicate a problem: in the face of various existing textual errors, does the Bible still have authority? Opponents of Biblical authority conclude that we cannot trust the text because of the serious nature of the textual problems. Proponents of Biblical authority take the opposite view and defend the authority of the Scriptures. Proponents argue that there is certainty regarding the meaning of the Bible despites its many textual errors. This is due to the fact that the textual changes do not significantly impact upon the meaning of the text. Additionaly, the numerous textual variants of available manuscripts provides us with an interverifying process to ascertain the meaning of the text. Moreover, the impossibility of scribal conspiration signifies historical reference and value within the text. The certainty of the meaning of the text has implications for the certainty of biblical authority. Finally, the author concludes that though there are textual errors within the Bible they do not negate the authority of the Bible.

Keywords: Bible Authority, Textual Error, Textual Criticism, The Certainty of the Text Meaning 


\section{Pendahuluan}

Salah satu atribut Alkitab berdasarkan warisan teologi reformed adalah bahwa Alkitab memiliki otoritas atas hidup orang percaya. ${ }^{1}$ Otoritas ini didasarkan pada keyakinan bahwa Alkitab diinspirasikan oleh Allah. ${ }^{2}$ Berpijak pada natur Allah yang sempurna dan natur manusia yang berdosa, para teolog injili ${ }^{3}$ percaya bahwa otoritas Alkitab merupakan hal yang harus ada bagi umat manusia. ${ }^{4}$ Di atas dasar kebenaran Alkitab yang berotoritas ini seluruh doktrin Kristen dibangun. Walaupun demikian, studi kritik tekstual Alkitab menunjukkan bahwa berbagai salinan Alkitab, PL dan PB, memiliki banyak kesalahan tekstual. ${ }^{5}$ Lee M. McDonald mengatakan:

${ }^{1}$ Cornelius Van Til, An Introduction to Systematic Theology, ed. William Edgar, ed. ke-2 (Phillipsburg: P\&R, 2007), 225-226.

${ }^{2}$ Menggarisbawahi hal ini, Robert C. Sproul mengatakan: "The Bible is called the Word of God because of its claim, believed by the church, that the human writers did not merely write their opinions, but that their words were inspired by God... . God breathed out the Bible" (Essential Truth of the Christian Faith [Illinois: Tyndale, 1992], 15).

${ }^{3}$ John M. Frame dalam The Doctrine of the Word of God (Phillipsburg: P\&R, 2010), 2, menyebutkan serangkaian nama teolog injili yang mendukung otoritas Alkitab. Mereka adalah Ernst W. Hengstenberg, Johann F. K. Keil, Franz Delitzsch, Theodor Zahn, Benjamin B. Warfield, Robert D. Wilson, Geerhardus Vos, John G. Machen, George E. Ladd, Frederick F. Bruce, Edward J. Young, Meredith G. Kline, Ned Stonehouse, Donald A. Carson, Richard Bauckham, dan Craig Blomberg. Selain itu, sarjana biblika terkemuka Gregory K. Beale juga berada pada pihak yang sama ("Can the Bible Completely Inspired by God and Yet Still Contain Errors? A Response to Some Recent 'Evangelical' Proposals," Westminster Theological Journal 73, no. 1 [Spring 2011]: 1-22).

${ }^{4} \mathrm{Bdk}$. Westminster Confession of Faith, I.4 yang menyatakan bahwa "The authority of the Holy Scripture, for which it ought to be believed, and obeyed, dependeth not upon the testimony of any man, or Church; but wholly upon God (who is truth itself) the author thereof: and therefore it is to be received, because it is the Word of God;" penekanan oleh penulis.

${ }^{5}$ Yang dimaksud dengan "kesalahan tekstual" dalam tulisan ini adalah segala bentuk kesalahan tulisan yang ada pada apograf (naskah salinan) dan terjemahan, yang berbeda dari autograf (naskah asli). Untuk PL, perhatikan Ellis Brotzman, Old Testament Textual Criticism: A Practical Introduction (Grand Rapids: Baker, 2006), 107-121; untuk PB, simak penelitian akademis Daniel B. Wallace dalam Revisiting the Corruption of the New Testament: Manuscript,
Those who study ancient biblical manuscripts know that all of these manuscripts differ from one another to greater or lesser degrees. While there are many common characteristics in several families of manuscript, no two biblical manuscripts are exactly identical. . . . Ancients manuscripts were therefore subject to human error, even those more meticulously coppied by the rabbies."

Menurut McDonald, proses transmisi yang panjang dari autograf kepada berbagai salinan bukan hanya berdampak pada luasnya keragaman salinan, tetapi juga pada kesalahan yang diakibatkan oleh kelalaian para penyalin. Bagi kelompok teolog tertentu, ${ }^{7}$ kesalahan ini memiliki implikasi doktrinal yang sangat serius. ${ }^{8}$ Masalah yang muncul ialah di hadapan fakta berbagai kesalahan tekstual yang ada, masihkah Alkitab memiliki otoritas? Ini yang menjadi fokus penelitian penulis.

Tulisan ini akan mendiskusikan: pertama, fakta dan problematika kesalahan tekstual. Pada bagian ini akan diuraikan contoh-contoh kesalahan tekstual dalam Perjanjian Lama dan Perjanjian Baru. Dengan mempertimbangkan keterbatasan ruang dan keterwakilan jenis kesalahan, bagian Alkitab yang dipilih hanya Kejadian 10:4 dan 1 Tawarikh 1:7; 1 Raja-raja 4:26 dan 2 Tawarikh 9:25; Habakuk 1:12; serta Yesaya 13:16 (untuk PL) dan 1 Korintus 13:3; Yohanes 17:15; Markus 1:41, 16:9-20; Yohanes 7:53-8:11; dan 1 Yohanes 5:7-8 (untuk PB). Selain itu, akan diuraikan juga apa saja

Patristic, and Apocryphal Evidence, ed. Daniel B. Wallace (Grand Rapids: Kregel, 2011), 19-55.

6"Lee M. McDonald, Where Lies Authority? A Discussion of Books, Texts, and Translations," dalam Exploring the Origins of the Bible: Canon Formation in Historical, Literary, and Theological Perspective, ed. Craig A. Evans dan Emanuel Tov (Grand Rapids: Baker Academic, 2008), 209; penekanan oleh penulis.

${ }^{7}$ Khususnya mereka yang melihat Alkitab hanya sebagai karya manusia dan menolak aspek inspirasi di dalamnya.

${ }^{8}$ Misalnya, kesalahan dalam teks 1 Yoh. 5:7-8 yang berkaitan erat dengan doktrin Tritunggal (Bart D. Ehrman, Misquoting Jesus: The Story behind Who Changed the Bible and Why [New York: HarperOne, 2007], 208; bdk. catatan kaki nomor 39). 
problematika di sekitar kesalahan tekstual dan argumen para oponen otoritas Alkitab; kedua, bagian berikutnya akan mendiskusikan secara teologis problematika ini dengan menyertakan argumen para proponen otoritas Alkitab. Diskusi teologis akan diberikan sebagai sebuah kajian terhadap argumen dari kedua pihak tersebut. Penulis berharap diskusi teologis yang dilakukan dapat menjadi sumbangsih akademis teologis yang mendalam terhadap studi ini karena terlepas dari berbagai kesalahan tekstual yang ada, penulis meyakini Alkitab masih memiliki otoritas.

\section{Fakta dan Problematika Kesalahan Tekstual}

Mengatakan bahwa teks-teks Alkitab memiliki kesalahan adalah hal yang tidak menyenangkan dan sangat mungkin mengusik iman tradisional. Namun pada faktanya, salinan Alkitab yang gereja miliki saat ini sarat dengan kesalahan tekstual. Sebagian kesalahan hanya berkisar pada perbedaan huruf, namun sebagian lain bersifat cukup mendasar. Kesalahan-kesalahan itu tersebar di sepanjang PL dan PB. ${ }^{9}$

\section{Kesalahan Tekstual dalam Perjanjian Lama}

Kritik tekstual PL menunjukkan bahwa umumnya kesalahan-kesalahan dalam PL tidak terlalu banyak. Paling tidak ini disebabkan oleh dua hal: pertama, status para penyalin. Salinan PL biasanya dilakukan oleh sekelompok resmi para penyalin saleh di bawah peraturan-peraturan yang ketat. ${ }^{10}$ Kedua, sikap para penyalin. Para Masoret

\footnotetext{
${ }^{9}$ Bukan intensi penulis untuk menyajikan data komprehensif kesalahan-kesalahan tekstual dalam PL maupun PB. Penulis juga tidak bertujuan untuk melakukan kritik teks mendalam (dengan mengkaji berbagai bukti internal dan eksternal yang ada) atas bagian-bagian kesalahan tersebut. Fokus penulis adalah pada adanya fakta kesalahan-kesalahan tekstual. Diskusi tekstual disajikan untuk membuktikan bahwa kesalahan-kesalahan tekstual itu memiliki implikasi yang signifikan dan besifat polemik dalam Alkitab.

${ }^{10} \mathrm{Hal}$ ini berbeda sekali dengan banyaknya kesalahan pada salinan PB yang disebabkan oleh status para penyalin yang tidak seluruhnya adalah penyalin resmi atau profesional (Norman Geisler dan William E. Nix, A General Introduction to the Bible [Chicago: Moody, 1986], 467-468).
}

biasanya "systematically destroyed all copies with 'mistaken' and/or variant readings." 11 Ini menjelaskan mengapa apograf (salinan) PL jauh lebih sedikit dibandingkan dengan PB. Secara umum, ada dua jenis kesalahan tekstual: kesalahan yang tidak disengaja dan yang disengaja. ${ }^{12}$

\section{Contoh Kesalahan Tekstual yang Tidak Disengaja}

Salah satu contoh umum mengenai hal ini adalah perbandingan kata "Dōdānîm" dan "Rōdānîm" dalam Kejadian 10:4 dan 1 Tawarikh 1:7. Brotzman mencermati hal ini demikian:

The textual apparatus of BHS for this verse indicates that some Hebrew manuscripts, the Samaritan Pentateuch, and the Septuagint all are in agreement with the text of 1 Chro-

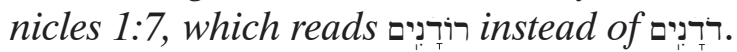
It seems evident that a confusion of $\mathbf{d}$ for $\mathbf{r}$ or $\mathbf{r}$ for $\mathbf{d}$ has occurred in one of these texts. Many hold, rightly in my opinion, that רוּרִניט is original because of a likely relation between the Rodanim and the Island of Rhodes. ${ }^{13}$

Aparatus tekstual BHS menunjukkan bahwa beberapa manuskrip Ibrani, Pentateukh Samaria, dan Septuaginta lebih mendukung pembacaan "Rōdānîm." Penulis sependapat dengan analisis tekstual Brotzman karena kesimpulannya didukung oleh manuskripmanuskrip tua lain di luar Masoretic Text (MT) dan juga argumen geografis. Namun bagi pembaca awam, hal ini dapat menjadi masalah. Pembaca awam mungkin akan menanyakan teks manakah yang benar antara Kejadian

\footnotetext{
${ }^{11}$ Ibid.
}

${ }^{12}$ Menurut Brotzman, kesalahan tekstual yang tidak disengaja dapat disebabkan oleh empat faktor: pertama, kesalahan yang berkaitan dengan manuskrip yang sedang disalin; kedua, berkaitan dengan kelalaian para penyalin; ketiga, berkaitan dengan problematika pendengaran; dan keempat, berkaitan dengan penilaian pikiran penyalin (Old Testament, 108-116).

${ }^{13}$ Ibid., 110; bdk. Karl Elliger dan Wilhelm Rudolph et al., ed., Biblia Hebraica Stuttgartensia (Stuttgart: Deutsche Bibelgesellschaft, 1987), 14; cetak tegak ada pada teks aslinya. 
10:4 dan 1 Tawarikh 1:7 berkaitan dengan kata "Dōdānîm" dan "Rōdānîm." Pembaca yang kritis dapat mempermasalahkan natur ilahi teks oleh karena kesalahan tekstual yang ada.

Contoh lain adalah masalah antara 1 Rajaraja 4:26 dengan 2 Tawarikh 9:25, berkaitan dengan jumlah kandang kuda yang dimiliki oleh Salomo. Apakah 40.000 kandang (1Raj. 4:26) atau hanya 4.000 kandang (2Taw. 9:25)? Lagi-lagi perbedaan ini menunjukkan kesalahan tekstual berkaitan dengan penyalinan manuskrip. Norman Geisler dan Thomas A. Howe menyatakan:

This is undoubtedly a copyist error. ... In the Hebrew language, the visual difference between the two numbers is very slight. ... The manuscripts from which the scribe worked may have been smudged or damaged and have given the appearance of being fourty thousand rather than four thousand. ${ }^{14}$

Perbedaan ini menunjukkan adanya kesalahan penyalinan karena perbedaan visual antara 40.000 dan 4.000 dalam bahasa Ibrani tidak terlalu kentara. Aparatus MT dalam 1 Raja-raja 4:26 menunjukkan bahwa Codex Vaticanus (B) lebih mendukung pembacaan 2 Tawarikh 9:25. ${ }^{15}$ Naskah manuskrip yang rusak memang berdampak pada perbedaan teks yang ada. Sekalipun perbedaannya hanya masalah antara ribuan dan puluhan ribu, kedua ayat ini tetap merupakan bagian dari kesalahan tekstual PL.

\section{Contoh Kesalahan Tekstual yang Disengaja}

Selain kesalahan yang tidak disengaja, para penyalin PL juga melakukan kesalahan yang disengaja. Salah satu contohnya adalah Habakuk 1:12 yang berbunyi: "Bukankah Engkau, ya TUHAN, dari dahulu Allahku, Yang Mahakudus? Tidak akan mati kami. Ya TUHAN, telah Kautetapkan dia untuk meng-

${ }^{14}$ Norman L. Geisler dan Thomas A. Howe, Making Sense of Bible Difficulties (Grand Rapids: Baker, 2009), 79; bdk. Geisler dan Nix, A General Introduction, 469.

\footnotetext{
${ }^{15}$ Ada perbedaan letak ayat antara versi Indonesia dengan Ibrani. Dalam BHS, ayat ini ada di 1 Raja-raja 5:6 (lih. Elliger, Biblia Hebraica Stuttgartensia, 568).
}

hukumkan; ya Gunung Batu, telah Kautentukan dia untuk menyiksa." Bagian yang bersifat problematis ada pada frasa "tidak akan mati kami." Aparatus MT menunjukkan Tiq soph atau tîqune soperîm, ${ }^{16}$ yaitu koreksi dari para penyalin. BHS menyarankan pembacaan "tidak akan mati Engkau."17 Brotzman berpendapat:

According to the scribal tradition, the text originally stated that "you (Yahweh) will not die." Christian D. Ginsburg argues from the parallelism and from the Targum rendering that this is the clear meaning of the passage, but apparently the scribes' sensibilities would not allow them to let the text stand as written. ${ }^{18}$

Menurut hemat Brotzman, besar kemungkinan, sikap hormat para penyalin kepada Allah Yahweh mendorong mereka untuk melakukan perubahan dalam salinan sehingga pembacaan yang ada menjadi seperti yang sekarang tertulis dalam MT.

Contoh lain berkaitan dengan kesalahan yang disengaja adalah eufemisme dalam Yesaya 13:16. Dalam MT, frasa "akan ditiduri" pada ayat tersebut ditulis (Kethiv) "akan diperkosa"19 namun dibaca (Qere) "akan ditiduri."20 Para penyalin menambahkan Qere dalam bagian ini sebagai "an expression evidently viewed as less offensive than the Kethiv and thus substituted for it." 21 Ini dimaksudkan untuk memperhalus makna yang dimaksud oleh

${ }^{16}$ Elliger, Biblia Hebraica Stuttgartensia, 1050. Christian D. Ginsburg mendaftarkan tidak kurang dari 16 tîqune soperîm dalam PL, di antaranya: Kej. 18:22; Bil. 11:15, 12:12; 1Sam. 3:13; 2Sam. 16:12, 20:1; Yer. 2:11; Yeh. 8:17; Hos. 4:7; Hab. 1:12; Zak. 2:12; Mal. 1:13; Mzm. 106:20; Ayb. 7:20; dan Rat. 3:20 (Introduction to the MassoreticoCritical Edition of the Hebrew Bible [New York: Ktav, 1966], 352-361, sebagaimana dikutip oleh Brotzman, Old Testament, 117-118).

${ }^{17}$ Ibid.

${ }^{18}$ Old Testament Textual Criticism, 117.

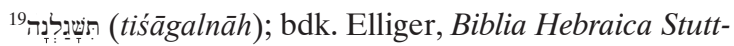
gartensia, 695

${ }^{20}{ }^{20}$ (tiśākāânañ

${ }^{21}$ Ibid., 120. 
teks tersebut. Keempat kasus PL di atas tidak dimaksudkan bersifat komprehensif, melainkan representatif berkaitan dengan fakta kesalahan-kesalahan tekstual dalam PL. Hal yang sama juga terjadi dalam naskah-naskah salinan PB.

\section{Kesalahan Tekstual dalam Perjanjian Baru}

Kesalahan-kesalahan tekstual dalam PB umumnya lebih banyak. Berbanding terbalik dengan PL, tidak seluruh penyalin PB adalah profesional atau penyalin resmi. Banyak di antara salinan tersebut merupakan "private and 'unofficial' copies." 22 Hal ini berdampak pada banyaknya jumlah salinan PB dan besarnya usaha yang harus dilakukan untuk merekonstruksi teks asli. ${ }^{23}$ Sama halnya dengan teks PL, secara umum, berbagai kesalahan tekstual dalam PB bersifat tidak disengaja dan disengaja.

\section{Contoh Kesalahan Tekstual yang Tidak Disengaja}

1 Korintus 13:3 mengilustrasikan hal ini. Kata yang mengandung masalah teks dalam ayat

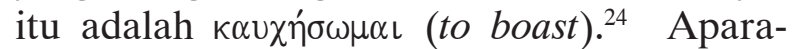
tus NA27 menunjukkan adanya dua pemba-

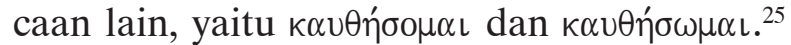

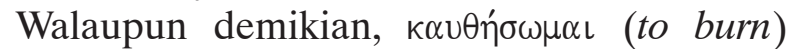
didukung oleh lebih banyak salinan termasuk manuskrip $\mathfrak{P}^{46}{ }^{26}$ Perbedaan antara aksara $\chi$ dan $\theta$ serta long vowel $\omega$ dan short vowel o kemungkinan disebabkan karena kemiripan

\footnotetext{
${ }^{22}$ Geisler dan Nix, A General Introduction, 468.

${ }^{23}$ Daniel B. Wallace memperkirakan bahwa "the handwritten copies of the NT contain a lot of differences. We are not sure exactly what the number is, but the best estimate is somewhere between 300,000 and 400,000 variants" ("Lost in Transmission: How Badly Did the Scribes Corrupt the New Testament Text?," dalam Revisiting the Corruption, 20).

${ }^{24}$ kauchēsōmai

${ }^{25}$ kauthēsomai dan kauthēsōmai.

${ }^{26}$ Salah satu manuskrip PB tertua yang termasuk dalam kategori I (lih. Kurt Aland, et al., ed., NestleAland: Novum Testamentum Graece, ed. ke-27 [Stuttgart: Bibelgesellschaft, 2006], 686). Manuskrip lain yang mendukung pembacaan ini ialah a A B 048. 33. 1739 yang notabene termasuk dalam kategori I dan II (ibid., 463).
}

bunyi di antara kedua pasangan huruf tersebut. ${ }^{27}$ Menyoroti hal ini, Geisler dan Nix mengatakan:

This kind of confusion occurred sometimes among the manuscripts, and some of them drastically affect the meaning of given passages. The confusion between the long vowel omega ( $\omega)$ and the short vowel omicron (o) arose as pronunciation changes occurred throughout history. ${ }^{28}$

Geisler dan Nix menunjukkan bahwa kesalahan ini mungkin terjadi karena perubahan bunyi kedua huruf vokal di atas. Ini menjelaskan mengapa beberapa manuskrip memiliki perbedaan hanya dalam satu huruf saja. Celakanya, menurut pihak oponen otoritas Alkitab, walaupun satu huruf, kesalahan itu memberikan perbedaan arti yang besar. ${ }^{29}$

Contoh lain adalah Yohanes 17:15, "Aku tidak meminta, supaya Engkau mengambil mereka dari [dunia, tetapi supaya Engkau melindungi mereka dari pada] yang jahat." Penyalin codex Vaticanus tidak menuliskan frasa yang ada dalam kurung tegak di atas. Aparatus NA27 juga menunjukkan bahwa frasa tersebut tidak dituliskan dalam beberapa salinan. ${ }^{30}$

\footnotetext{
${ }^{27}$ Geisler dan Nix, A General Introduction, 469-470; bdk. Bruce M. Metzger dan Bart D. Ehrman, The Text of the New Testament: Its Transmission, Corruption, and Restoration, ed. ke-4; (Oxford: Oxford University, 2005), 254257.

${ }^{28}$ Geisler dan Nix, A General Introduction, 470. Senada dengan hal ini, Metzger dan Ehrman mengatakan bahwa "confusion would sometimes arise over words having the same pronunciation as other, but different in spelling" (The Text of the New Testament, 190).

${ }^{29}$ Ambil contoh kesalahan tekstual yang dilakukan oleh penyalin codex Claromontanus yang mengganti " $\alpha \pi \in i \theta \epsilon i \alpha \varsigma$ " (disobedience) dengan “ $\alpha \lambda \eta \theta \epsilon i \alpha \varsigma$ ” (truth) dalam Ibrani 4:11. Kesalahan ini tidak hanya mengubah kata, tetapi juga makna yang bertolak belakang antara "ketidaktaatan" dengan "kebenaran" (Metzger dan Ehrman, The Text of the New Testament, 192; bdk. Aland, Nestle-Aland, 568).

${ }^{30}$ Aland, Nestle-Aland, 306.
} 
Agaknya, ini karena parablēpsis ${ }^{31}$ yang difasilitasi oleh homōeoteleuton. ${ }^{32}$

\section{Contoh Kesalahan Tekstual yang Disengaja}

Beberapa contoh kesalahan tekstual PB yang disengaja adalah Markus 1:41; 16:9-20; Yohanes 7:53-8:11; dan 1 Yohanes 5:7-8. ${ }^{33}$ Bagianbagian ini sering kali disoroti dan diperdebatkan oleh para peneliti teologi, khususnya dalam ranah kritik teks. ${ }^{34}$

\section{Markus 1:41}

Kata yang bersifat problematis adalah $\sigma \pi \lambda \alpha \gamma$ $\chi \nu\llcorner\sigma \theta \in i \varsigma$ (tergerak oleh belas kasihan). Pembacaan ini didukung oleh banyak versi terjemahan. ${ }^{35}$ Namun, baru-baru ini, penelitian kritik teks menunjukkan bahwa pembacaan

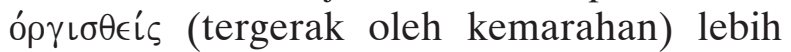
mendekati teks aslinya. Daniel B. Wallace menyetujuinya demikian:

Although most MSS here say that Jesus was moved with compassion when he healed a leper, we both agree that the original text probably said that he was angry when he did so. One of Ehrman's finest pieces is his provocatively titled article "A Leper in the Hands of An Angry Jesus." He there gave very strong evidence that Mark 1.41 spoke of Jesus' anger rather than his compassion. I agree. ${ }^{36}$

\footnotetext{
${ }^{31}$ Pembacaan yang terlewati, biasanya terjadi karena ada beberapa kata yang sama (Metzger dan Ehrman, The Text of the New Testament, 253).

${ }^{32}$ Kesamaan atau kemiripan akhiran pada suatu kata,

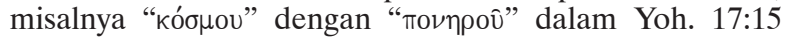
(ibid.).

${ }^{33}$ Daniel B. Wallace, "The Gospel According to Bart: A Review Article of Misquoting Jesus by Bart Ehrman," Journal of the Evangelical Theological Society 49, no. 2 (June 2006): 335.
}

${ }^{34}$ Beberapa ahli yang sering memperdebatkan bagianbagian ini adalah Daniel B. Wallace, Bart Ehrman, Mark A. Proctor, dan William D. Mounce (ibid.).

${ }^{35}$ Misalnya, "moved with pity" (ESV dan RSV); "moved with compassion" (KJV dan NASB); "filled with compassion" (NIV).

36"Lost in Transmission," 21; bdk. diskusi akademis dari penulis yang sama dalam "The Gospel According to Bart," 340-342.
Menurut Wallace, analisis Ehrman tentang ayat ini sangat tepat, yaitu bahwa Yesus tergerak oleh kemarahan, bukan oleh belas kasihan. Sekalipun bukan pendapat umum, pendapat Ehrman dan Wallace tidak dapat diabaikan begitu saja. Perubahan ini paling tidak disebabkan oleh dua hal: pertama, para penyalin sangat menaruh sikap hormat kepada Tuhan Yesus sehingga mereka meng-

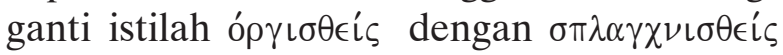
untuk memperhalus makna teks; ${ }^{37}$ kedua,

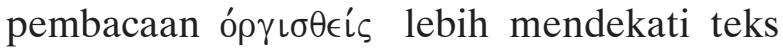
aslinya karena faktor pembacaan yang lebih sulit. $^{38}$ Yang mana pun juga, tampak terlihat usaha penyalin untuk mengubah teks aslinya.

\section{Markus 16:9-20; Yohanes 7:53-8:11; dan 1 Yohanes 5:7b-8a}

Umumnya, para peneliti teologi sepakat bahwa perikop-perikop ini tidak ada pada teks aslinya. ${ }^{39}$ Penelitian kritik teks menunjukkan bahwa perikop di atas ditambahkan oleh penyalin setelah naskah asli selesai ditulis. ${ }^{40}$ Beberapa versi terjemahan memisahkan perikop ini dari teks sebelum atau setelahnya. NA27 sendiri memberikan tanda [[ ]] (double brackets) untuk menunjukkan bahwa "the enclosed words, generally of some length, are known not to be a part of the original text." 41 Kata-kata yang ada dalam kurung siku ganda tersebut bukan bagian dari teks asli. Bagian ini sangat menunjukkan adanya usaha penya-

\footnotetext{
${ }^{37}$ Lih. Mark A. Proctor, "The 'Western' Text of Mark 1:41: A Case for the Angry Jesus" (Ph.D. diss., Baylor University, 1999) sebagaimana dikutip oleh Wallace dalam "The Gospel According to Bart," 340. Mendukung hal ini, Gordon D. Fee mengatakan: "the vast majority of 'deliberate' variants were attempts to 'improve' the text in some way - to make it more readable and/or understandable" (New Testament Exegesis [Louisville: Westminster John Knox, 2002], 61).

${ }^{38}$ Wallace, "The Gospel According to Bart," 340.

${ }^{39}$ Menggarisbawahi hal ini, Wallace mengatakan bahwa ketiga bagian Alkitab tersebut "have been considered inauthentic by most NT scholars - including most evangelical NT scholars - for well over a century" (Wallace, "Lost in Transmission," 44; penekanan ada pada teks aslinya).

${ }^{40}$ Ibid., 21.

${ }^{41}$ Aland, Nestle-Aland, 50, 147-149, 273-274; penekanan oleh penulis.
} 
lin yang sengaja menambahkan pada teks aslinya. Ehrman menyindir dengan tajam:

It would be wrong . . . to say - as people sometimes do - that the changes in our text have no real bearing on what the text mean or on the theological conclusions that one draws from them. . . . In some instances, the very meaning of the text is at stake, depending on how one resolves a textual problem: ... Did he (Jesus) tell his disciples that they could drink poison without being harmed [Mark 16.9-20]? Did he let an adulteress off the hook with nothing but a mild warning [John 7.53-8.11]? Is the doctrine of the Trinity explicitly taught in the New Testament [1 John 5.7-8]? ?2

Dalam kutipan di atas, Ehrman mempertanyakan otentisitas pengajaran Yesus dalam perikop-perikop di atas. Ia juga meragukan historisitas pengajaran Trinitas dalam 1 Yohanes 5:7-8. Suara Ehrman tidak bergema di ruang hampa. Kesalahan-kesalahan tekstual dalam Alkitab adalah fakta dan menyisakan problematika yang tidak mudah untuk diselesaikan.

\section{Problematika Kesalahan Tekstual: Oponen Berargumen}

Bagi pihak yang menentang otoritas Alkitab, masalahnya cukup jelas. Pertama, berbagai kesalahan tekstual mengimplikasikan ketidakpastian makna teks. Jika Alkitab sarat dengan kesalahan tekstual, bagaimana mungkin kita dapat merekonstruksi autograf? Ehrman menyarikan poin ini dengan jelas ketika mengatakan:

Given these problems, how can we hope to get back to anything like the original text, the text that an author actually wrote? It is an enormous problem. In fact, it is such an enormous problem that a number of textual critics have started to claim that we may as well suspend any discussion of the "original" text, because it is inaccesible to us. ${ }^{43}$

\footnotetext{
${ }^{42}$ Ehrman, Misquoting Jesus, 207-208.

${ }^{43}$ Ibid., 58.
}

Ehrman menyatakan bahwa dengan begitu banyaknya kesalahan tekstual, agaknya sulit sekali untuk merekonstruksi teks asli. Apa yang Ehrman katakan tampaknya tidak terlalu berlebihan. Masalahnya ialah sangat mungkin "that a scribe will sometimes correct the correct manuscript in light of the wording of the incorrect one." 44 Terlepas dari niat baik seorang penyalin untuk membenarkan sebuah teks (mengingat banyaknya jumlah salinan yang ada dan besarnya kemungkinan terjadinya kesalahan dalam penyalinan), agaknya sulit untuk memastikan bahwa seorang penyalin tidak mungkin mengubah teks dari benar menjadi salah. Tidak heran Ehrman menilainya sebagai "an enormous problem." 45 Masalah ini dilipatgandakan dengan natur penelitian yang terus berproses. Keputusan terhadap kata atau frasa tertentu hari ini mungkin berubah oleh karena penemuan atau penelitian baru di masa depan. ${ }^{46}$ Dalam kondisi penelitian yang terus berproses, mungkinkah kepastian makna teks dihasilkan? Bagi para oponen, jawabannya jelas tidak!

Kedua, ketidakpastian makna teks mengimplikasikan hermeneutika yang relatif. Tanpa kepastian makna teks, mungkinkah pembaca saat ini benar-benar mengerti apa yang sebenarnya ingin disampaikan penulis Alkitab? Robert W. Funk menjawab dengan mantap bahwa "even careful copyists make mistakes, as every proofreader knows. So we will never be able to claim certain knowledge of exactly what the original text of any biblical writing was." 47 Menurut Funk, berbagai kesalahan salinan meniadakan kepastian tentang apa yang ingin disampaikan oleh penulis Alkitab mula-mula. Lebih jauh lagi, para oponen berargumen, mungkinkah kita dapat benar-benar mengerti

\footnotetext{
${ }^{44}$ Ibid.; penekanan pada teks aslinya.

${ }^{45}$ Ibid.

${ }^{46}$ John J. Collins, The Bible after Babel (Grand Rapids: Eerdmans, 2005), 10 .

${ }^{47}$ Robert W. Funk, Roy W. Hoover, dan the Jesus Seminar, The Five Gospels: The Search for the Authentic Words of Jesus (New York: Macmillan, 1993), 6, sebagaimana dikutip oleh Wallace, "Lost in Transmission," 22; penekanan ada pada teks aslinya.
} 
apa yang sebenarnya ingin Tuhan sampaikan? Tidakkah ketidakpastian makna teks membuka ruang bagi proses hermeneutika yang relatif? ${ }^{48}$ Collins memaknainya demikian:

It should be clear, however, that ethical principles, or theological truth, are not simply given by the Bible, regardless of whether one operates within a historical-critical or postmodernist paradigm. The internal pluralism of the Bible, both theological and ethical, has been established beyond disputed. ${ }^{49}$

Merujuk pada apa yang Collins katakan di atas, pluralisme internal Alkitab adalah frasa yang menunjukkan adanya ruang bagi dialog akademis dalam hermeneutika, baik dalam isu teologis maupun etis. Namun, Collins mempertajam maksudnya bahwa "in this context, the truth claims of the discipline are relative." ${ }^{50}$ Akibatnya, makna teks ditentukan oleh siapa yang membaca, menafsirkan, dan meneliti teks tersebut.

Ketiga, hermeneutika yang relatif mengimplikasikan segala pengajaran yang relatif. Hermeneutika yang relatif erat kaitannya dengan makna teks yang berlapis. Dalam keragaman makna teks yang multitafsir, mungkinkah Alkitab dapat menghasilkan prinsip-prinsip kebenaran (apalagi doktrinal) yang bersifat ajek, absolut, dan dapat diandalkan? Berpijak pada fondasi hermeneutika Alkitab yang demikian, para oponen melihat seluruh bangunan pengajaran di atasnya akan bersifat tidak pasti. Wallace menggarisbawahinya dengan tepat ketika mengatakan "the cumulative effect of these latter statements seems to be not only that we have no certainty about the wording of the original but that, even where we are sure of the wording, the core theology is not

${ }^{48}$ Katharine D. Sakenfeld menegaskan bahwa teks Alkitab adalah untuk semua orang dari semua golongan. Sekalipun tidak secara langsung menyetujui hermeneutika relatif, baginya, hermeneutika satu makna bukan hanya mustahil, tetapi juga merupakan sikap yang tidak toleran ("Whose Text Is It?," Journal of Biblical Literature 127, no. 1 [Spring 2008]: 5-18).

\footnotetext{
${ }^{49}$ Collins, The Bible after Babel, 160-161; penekanan oleh penulis.
}

${ }^{50}$ Ibid., 11. as nearly as 'orthodox' as we had thought." 51 Maksudnya ialah dampak kesalahan tekstual bukan hanya pada ketidakpastian penafsiran kata, tetapi juga pada ketidakpastian ortodoksi pengajaran. Pada bagian ini doktrin Kristen menjadi kehilangan nilai ortodoksinya karena relativitas makna teks.

Keempat, kesimpulan di atas membawa kita kepada polemik teologis. Alkitab dengan pengajaran yang relatif tidak mungkin memiliki otoritas yang absolut, apalagi otoritas ilahi. Konsekuensi logisnya tidak dapat dihindari, yaitu pengajaran yang relatif mengimplikasikan ketiadaan otoritas absolut. Tidak heran McDonald mengatakan bahwa "the problem remains that we still do not have an established authoritative text that all Christian biblical scholars have adopted." 52 Masalah yang masih ada ialah tidak adanya teks otoritatif yang sahih di mana seluruh sarjana Alkitab menerimanya. Itulah sebabnya, bersama dengan N. T. Wright, seorang sarjana biblika yang sangat dihormati, McDonald mengusulkan bahwa "final authority for the church resides in the One who comes to us through the biblical text, but not in the text itself." "53 Menurut McDonald, otoritas final bagi gereja terletak pada Pribadi yang datang melalui teks Alkitab, tetapi bukan pada teks Alkitab itu sendiri. Walaupun demikian, Wright tetap mengakui otoritas Alkitab dalam pemaknaan transformatif, bukan normatif. ${ }^{54}$ Maksudnya, otoritas Alkitab tidak boleh dimengerti sebagai kumpulan aturan dan doktrin yang mengikat, melainkan sebagai kuasa Allah untuk

\footnotetext{
${ }^{51}$ Wallace, "Lost in Transmission," 25.

${ }^{52}$ McDonald, "Where Lies Authority?," 238.

${ }^{53}$ Ibid., 238-239. Nicholas T. Wright mengatakan bahwa "the Bible itself declares that all authority belongs to the one true God, and that this is now embodied in Jesus himself" (The Last Word: Scripture and the Authority of God - Getting beyond the Bible Wars [New York: HarperCollins, 2005], xi); lihat juga diskusi akademis oleh penulis yang sama dalam "How Can the Bible Be Authoritative?," Vox Evangelica 21 (1991): 7-32, http://ntwrightpage.com/ Wright_Bible_Authoritative.htm; diakses pada 14 Okto-

${ }^{54}$ Ibid., 16; bdk. Christian Smith, The Bible Made Impossible: Why Biblicalism Is Not a Truly Evangelical Reading of Scripture (Grand Rapids: Brazos, 2012), 94.
} ber 2014 . 
mengubah (mentransformasi) hidup di mana Allah menyatakan kerajaan-Nya dalam dunia dan hati manusia.

Dari keempat rumusan problematika di atas, dapat ditarik alur kesimpulan bahwa berbagai kesalahan tekstual dalam Alkitab mengimplikasikan ketidakpastian makna teks. Ketidakpastian makna teks mengimplikasikan hermeneutika yang relatif. Hermeneutika yang relatif mengimplikasikan segala pengajaran yang relatif, dan pengajaran yang relatif mengimplikasikan ketiadaan otoritas absolut dalam Alkitab. Kesimpulan akhir yang dapat dirumuskan adalah berbagai kesalahan tekstual mengindikasikan ketiadaan otoritas absolut Alkitab. Poin ini perlu dikaji dalam diskusi teologis yang mendalam.

\section{Diskusi Teologis Problematika Otoritas Alkitab dalam Masalah Kesalahan Tekstual}

Uraian dari pihak oponen di atas tidak dapat diabaikan begitu saja. Argumentasi yang dibangun juga sangat beralasan. Namun, pihak proponen juga memiliki argumennya sendiri.

\section{Proponen Menanggapi}

Ambil contoh Jeffrey Khoo, dekan akademis dan dosen Perjanjian Baru di Far Eastern Bible College (FEBC), Singapura yang menanggapi isu ini dengan sangat serius. Khoo menulis banyak artikel yang membela otoritas Alkitab berkaitan dengan isu kesalahan tekstual dalam jurnal akademis FEBC, The Burning Bush. ${ }^{55}$ Khoo berargumen bahwa pengakomodasian dan penggunaan kritik teks merupakan titik kejatuhan bibliologi sebagaimana dinyatakannya, "textual criticism introduced by Princeton Seminary is the Trojan horse in Reformed, evangelical, and fundamentalist Biblio-

\footnotetext{
${ }^{55}$ Contohnya: "Inspiration, Preservation, and Translations: In Search of the Biblical Identity of the Bible - Presbyterian Church," The Burning Bush 13 no. 1 (January 2007): 4-23; "Can Verbal Plenary Inspiration Do Without Verbal Plenary Preservation? The Achilles Heel of Princeton Bibliology," The Burning Bush 13 no. 1 (January 2007): 25-43; dan "Lost Word in Our Bible?," The Burning Bush 13 no. 1 (January 2007): 44-49.
}

logy today." ${ }^{56}$ Kritik teks ibarat "musuh dalam selimut" bagi bibliologi yang sehat. Mengapa demikian? Khoo melihat bahwa metode kritik teks berakar pada rasionalitas skolastiksisme yang mengagungkan rasio di atas segalanya. ${ }^{57}$ Dalam konsepsi teologis Khoo, kesempurnaan Alkitab tanpa kesalahan tekstual bukan hanya ada pada autograf, tetapi juga pada apograf. Ini dimungkinkan karena adanya providentia extraordinaria dari Allah. ${ }^{58}$ Jika demikian, teks Alkitab manakah yang sempurna itu? Khoo menjawab bahwa "the KJV is the closest to the purest Bible in the original languages that our all-powerful God has supernaturally preserved and His spirit-indwelt Church has faithfully received throughout the ages." 59 Ia berpendapat bahwa Alkitab versi King James paling mendekati autograf. Bagi Khoo, nyaris tidak ada problematika antara kesalahan tekstual dengan otoritas Alkitab, bahkan boleh dikatakan, tidak ada kesalahan tekstual.

Teladan Khoo diikuti dengan baik oleh Paul Ferguson, seorang mahasiswa FEBC program doktoral teologi. Dalam tulisannya, "The Battle over Presupposition on the Textual Issue," 60 Ferguson berargumen bahwa prasuposisi yang alkitabiah harus menjadi titik awal yang kuat demi menghasilkan bibliologi yang sehat. Mengapa demikian? Ia menjelaskan bahwa cara pandang seseorang terhadap Alkitab menentukan sikap orang tersebut terhadapnya. Ferguson tidak setuju dengan kritik teks karena:

\footnotetext{
${ }^{56}$ Ibid., 25.
}

${ }^{57}$ Ibid.

${ }^{58}$ Ibid., 34; bdk. Jeffrey Khoo, "John Owen on the Perfect Bible” 10, no. 2 (July 2004): 76.

${ }^{59}$ Ibid., 17. Para dosen dan anggota yayasan FEBC bahkan mengucapkan Sumpah "Dean Burgon," di mana poin (6) dan (7) dari sumpah itu mengatakan bahwa "I do not believe there are any scribal errors in our present Bible, and any alleged errors are only apparent and not errors at all. ... I do not want to play textual critic, and be a judge of God's Word" (Jeffrey Khoo, "A Plea for A Perfect Bible" 9, no. 1 [January 2003], 15).

${ }^{60}$ Paul Ferguson, The Burning Bush 16, no. 1 (January 2010): 22-45. 
Textual critical evidential arguments presuppose that man can approach the knowledge of God's Words, as if man is morally neutral. It is predicated on the idea that man has an unaided intrinsic ability to reach knowledge of God's Words in making textual choices and conjectural emendations. ${ }^{61}$

Menurut Ferguson, tanpa pertolongan supranatural, dosa menutup kemungkinan manusia menjadi seorang peneliti yang netral secara moral. Karenanya, iman harus selalu mendahului dialektika akademis, bahkan memimpin dan mengkritisinya. Butir kebenaran ini sangat mirip dengan pendekatan John M. Frame, seorang teolog sistematika ternama.

Dalam buku keempat, The Doctrine of the Word of God dari empat seri $A$ Theology of Lordship, Frame menguraikan panjang lebar mengenai berbagai aspek bibliologi. Bab kedua, bagian ketiga dari buku tersebut menyoroti secara khusus tentang otonomi manusia sebagai nilai sentral pandangan modern tentang Alkitab. Frame mengatakan:

But within the liberal movement itself, there was no consideration of the alternative. Intellectual autonomy was accepted as a presupposition, as something fundamental, not to be argued about. It was thought that anyone who disagreed was simply not a scholar, not qualified to do serious research. ${ }^{62}$

Kutipan di atas menunjukkan bahwa otonomi intelektual sebagai sebuah prasuposisi dasar mencirikan gerakan liberal. Walaupun demikian, sebagai seorang sarjana, Frame tidak menihilkan nilai intelek. Sebaliknya, ia menegaskan bahwa intelek harus digunakan untuk memuliakan Tuhan. Keberatan Frame terhadap liberalisme bukan "a complaint against reason itself, but against the propositions (1) that human reason operates autonomously, and (2) that autonomous reason provides the ultimate criteria of truth and falsity, right and wrong, by which everything (including Scrip-

\footnotetext{
${ }^{61}$ Ibid., 27.

${ }^{62} \mathrm{John}$ M. Frame, The Doctrine of The Word of God (Phillipsburg: P\&R, 2010), 19; penekanan oleh penulis.
}

ture) is to be judged." 63 Frame tidak alergi terhadap rasio, tetapi ia menentang otonomi rasio sebagai kriteria tertinggi menilai kebenaran.

Namun berbeda dengan Khoo, Frame tetap mengakui adanya problematika tekstual sambil tetap menekankan bahwa hal itu sama sekali tidak memengaruhi otoritas Alkitab. Ini disebabkan karena dua hal: ${ }^{64}$ pertama, kesalahan-kesalahan tekstual bersifat minor, artinya tidak memengaruhi doktrin dasar iman Kristen; dan kedua, Alkitab bersifat "highly redundant in a good way." Maksudnya, ketidakpastian dalam satu bagian Alkitab akan dijelaskan atau dilengkapi oleh bagian Alkitab lain yang lebih jelas.

Akhirnya, diskusi ini tidaklah lengkap tanpa menghadirkan seorang pembela otoritas Alkitab lain, khususnya dalam ranah kritik teks, Wallace. Dalam artikel akademis "The Gospel According to Bart: A Review Article of Misquoting Jesus by Bart Erhman," Wallace berargumen bahwa sekalipun ada banyak kesalahan tekstual dalam Alkitab, mereka sama sekali tidak memengaruhi doktrindoktrin utama kekristenan. ${ }^{65}$ Dengan lebih spesifik, ia menyoroti tujuh bagian Alkitab yang dipermasalahkan oleh Ehrman: Markus 16:9-20, Yohanes 7:53-8:11, 1 Yohanes 5:78, Ibrani 2:8-9, Markus 1:41, Matius 24:36, dan Yohanes 1:18. Diskusi yang lebih tajam Wallace lakukan dalam "Lost in Transmission: How Badly Did the Scribes Corrupt the New Testament Text?"66 Dalam tulisan tersebut, ia berargumen bahwa berbagai kesalahan tekstual pada dasarnya tidak memengaruhi otoritas Alkitab karena tiga hal::7 pertama, jumlah varian dengan usia tua sangat banyak sehingga mendekati teks aslinya; kedua, natur dari kesalahan tekstual itu sangat minor

\footnotetext{
${ }^{63}$ Ibid., 21.

${ }^{64}$ Ibid., 248.

${ }^{65}$ Wallace, "The Gospel According to Bart," 335.

${ }^{66}$ Daniel B. Wallace, "Lost in Transmission: How Badly Did the Scribes Corrupt the New Testament Text?," dalam Revisiting the Corruption, 19-55.
}

${ }^{67}$ Ibid., 26-49. 
sehingga hampir tidak bermakna; dan ketiga, poin satu dan dua di atas meniadakan isu teologis dalam kesalahan tekstual.

Baik oponen maupun proponen memiliki argumen yang meyakinkan. Namun, analisis lebih jauh perlu dilakukan untuk mendapatkan kesimpulan yang memadai mengenai topik ini.

\section{Ke(tidak)pastian Makna}

Argumen tentang ketidakpastian makna yang digagas oleh pihak oponen tampak sangat meyakinkan. Namun, argumen ini lemah karena beberapa hal. Pertama, sekalipun tidak menutup kemungkinan para penyalin mengubah teks dari benar menjadi salah, perubahan tersebut nyaris tidak signifikan. Wallace kembali mengingatkan bahwa "of the hundred of thousands of textual variants in NT MSS, the great majority are spelling differences that have no bearing on the meaning of the text." 68 Dari ratusan ribu varian teks, sebagian besar kesalahannya terletak pada perbedaan ejaan yang tidak berdampak signifikan terhadap makna teks. Tetapi bagaimana dengan teks PL? Kesalahan tekstual dalam PL memang lebih sedikit namun lebih serius mengingat ketiadaan autograf PL. Akan tetapi, natur kesalahan yang sangat minor nyaris tidak berdampak pada makna teks secara keseluruhan. Karenanya, tidak terlalu berlebihan jika Brotzman mengatakan:

While it is important to recognize the possible existence of errors in the ancient manuscripts, early translations, and even modern editions, this is no way destroys the credibility of the inspired Scriptures, whether of the Old or New Testament. The vast majority of the Old Testament text is certain, and the variants that do exist can in most cases be resolved into primary and secondary readings. ${ }^{69}$

Terlepas dari pentingnya mengenai berbagai kesalahan tekstual, sebagian besar makna teks PL ialah pasti dan berbagai perbedaan

\footnotetext{
${ }^{68}$ Ibid., 40. lis.
}

yang dimunculkan oleh beragam varian dapat diselesaikan melalui analisis kritik tekstual.

Kedua, penulis melihat dengan banyaknya jumlah varian yang ada, khususnya $\mathrm{PB}$, alihalih mengaburkan makna teks, sebaliknya malah memperkuat kepastiannya. ${ }^{70}$ Wallace menyetujuinya demikian, "Altogether, there are more than 2.6 million pages of texts, leaving hundreds of witnesses for every book of the NT." ${ }^{\prime 1}$ Menurut Wallace, banyaknya jumlah varian menegaskan banyaknya jumlah kesaksian yang menguatkan kitab PB. Semakin banyak jumlah salinan, semakin menguji kepastian makna teks karena berbagai salinan tersebut saling memverifikasi, menguji, dan melengkapi satu sama lain. ${ }^{72}$

Ketiga, natur dari keragaman varian membantah argumen propaganda atau konspirasi dalam penyalinan. Jika para penyalin melakukan konspirasi, seharusnya salinan yang ada sangat mirip satu dengan yang lain (jika tidak ingin dikatakan sama persis). Namun, perbedaan-perbedaan yang muncul dalam bentuk kesalahan-kesalahan tekstual membuktikan bahwa "there was no conspiracy, just good practices." 73 Fakta ini menegaskan bahwa salinan Alkitab memiliki nilai historisitas yang tinggi. Seperti dinyatakan Wallace, "the transmission of the text was a growing, living thing, not constrained by ecclesiastical controls until long after Christianity became legalized."74 Proses transmisi teks Alkitab bersifat dinamis dan tidak dikungkung oleh kekuasaan tertentu. Nilai historisitas teks berkontribusi terhadap kepastian makna teks. Maksudnya adalah teks Alkitab, terlepas dari kesalahan tekstual yang ada, tetap memiliki makna yang pasti karena ada nilai dan rujukan historis di dalamnya. Dengan demikian, gugurlah tuduhan bahwa berbagai kesalahan tekstual mengimplikasikan ketidakpastian makna teks.

\footnotetext{
${ }^{70}$ Bdk. Wallace, "Lost in Transmission,” 26-27.

${ }^{71}$ Ibid., 28.

${ }^{72}$ Ibid.

${ }^{73}$ Ibid., 36.

${ }^{74}$ Ibid., 37; penekanan oleh Wallace.
} 
Kepastian makna teks ini memiliki implikasi yang luas. Karena makna teks bersifat pasti, hermeneutika yang relatif menjadi tidak berlaku. Sebaliknya, hermeneutika berusaha mengejar kepastian makna teks tersebut. Hermeneutika yang demikian tentunya menghasilkan butir-butir pengajaran yang dapat diandalkan. ${ }^{75}$ Kepastian pengajaran ini mengimplikasikan kepastian otoritas dalam Alkitab. Namun, bagaimana dengan proposal McDonald dan Wright bahwa otoritas hanya ada pada Yesus dan bukan pada teks Alkitab?

\section{Otoritas Ada pada Yesus, Bukan pada Alkitab?}

Merujuk pada Matius 28:18, proposal McDonald dan Wright menggarisbawahi bahwa segala otoritas ${ }^{76}$ telah diberikan kepada Yesus yang bangkit. Mereka berusaha memberikan semacam "middle ground way out" bagi polemik kemustahilan natur otoritas dalam Alkitab. ${ }^{77}$ Namun, ada beberapa hal yang menjadi permasalahan dari proposal tersebut. Pertama, ayat ini memang menegaskan bahwa Kristus yang bangkit telah menerima segala otoritas. Tetapi, baik ayat ini ataupun perikop tersebut secara keseluruhan tidak membantah bahwa firman Tuhan memiliki otoritas ilahi. Penulis tidak melihat adanya indikasi bahwa kebangkitan Kristus dengan otoritas penuh yang dimiliki-Nya meniadakan otoritas Alkitab. ${ }^{78}$

Kedua, jika McDonald dan Wright sepakat bahwa Kristus yang bangkit itu memiliki segala otoritas, tidakkah perkataan-Nya (dalam hal ini, segala firman yang diinspira-

\footnotetext{
${ }^{75}$ Butir-butir pengajaran di sini mengacu kepada segala bentuk pengajaran Alkitab, baik yang bersifat doktrinal (misalnya: keilahian Kristus, akhir zaman, dosa, dan manusia) atau pun etika moral (misalnya: perihal mengampuni, kasih, dan menolong sesama).

${ }^{76}$ LAI menerjemahkan dengan "segala kuasa".

${ }^{77}$ Di satu sisi, McDonald dan Wright mengakui keseriusan fakta kesalahan tekstual yang diangkat oleh pihak oponen. Namun di sisi yang lain, mereka juga berusaha mengakomodasi konsep otoritas yang diusung oleh pihak proponen.
}

${ }^{78} \mathrm{McDonald}$ dan Wright pun tidak menjelaskan hal ini dalam tulisan mereka.
sikan-Nya untuk dituliskan) juga memiliki otoritas? Konsekuensi logisnya tidak dapat dihindarkan. Jika titah (atau perkataan) seorang raja memiliki otoritas, mungkinkah perkataan Kristus, Sang Raja di atas segala raja yang telah bangkit dan menang, kehilangan otoritas-Nya? Sebaliknya, kebangkitan itu mengukuhkan otoritas, baik Pribadi maupun perkataan-Nya. ${ }^{79}$

Ketiga, Wright mengartikan otoritas Alkitab secara transformatif (mengubah hidup dan hati manusia), ${ }^{80}$ bukan normatif (menyatakan otoritas ilahi atas hidup manusia). Kenyataannya, transformasi baru dapat terjadi jika ada kuasa (otoritas) ilahi yang menyertai. ${ }^{81}$ Menghilangkan otoritas ilahi dari firman sama dengan melumpuhkan kuasa transformatif tersebut. ${ }^{82}$ Dengan kata lain, untuk membuat firman bersifat transformatif, diperlukan kualitas normatif di dalamnya.

Akhirnya, proposal McDonald dan Wright bertentangan dengan The Chicago Statement on Biblical Inerrancy. ${ }^{83}$ Sejak awal sekali, Article I bagian pertama menyatakan: "We affirm that the Holy Scriptures are to be received as the authoritative Word of God." 84 Berbeda dengan McDonald dan Wright, The Chicago Statement tanpa ragu mengafirmasi bahwa Alkitab, PL dan PB, ialah firman Allah yang berotoritas. ${ }^{85}$

\footnotetext{
${ }^{79}$ Menyoroti Matius 28:18, John Nolland mengatakan: "Jesus' freshly confirmed authority is the basis for his new directive now to the disciples" (The Gospel of Matthew, NIGTC; [Grand Rapids: Eerdmans, 2005], 1265; bdk. Leon Morris, The Gospel According to Matthew, PNTC; [Grand Rapids: Eerdmans, 1992], 746; dan Michael J. Wilkins, Matthew, NIVAC; [Grand Rapids: Zondervan, 2004], 951).
}

${ }^{80}$ Bdk. catatan kaki no. 55 .

${ }^{81} \mathrm{Bdk}$. Frame, The Doctrine of the Word of God, 523.

${ }^{82}$ Ibid.

${ }^{83}$ Sebuah pengakuan iman injili tentang ineransi Alkitab. Lihat bagian apendiks 2 tentang "The Chicago Statement on Biblical Inerrancy" dalam tulisan Robert C. Sproul, Scripture Alone (Phillipsburg: P\&R, 2005), 177193.

${ }^{84}$ Ibid., 180; penekanan oleh penulis.

${ }^{85}$ Penulis tidak meragukan kualitas injili dari berbagai konsepsi teologis McDonald dan Wright. Namun, pada 
Agaknya, Wright perlu mempertimbangkan hal-hal di atas ini.

Dengan mempertimbangkan diskusi di atas, penulis menyimpulkan: pertama, fakta kesalahan tekstual tidak meniadakan kepastian makna teks yang mengimplikasikan otoritas absolut Alkitab; kedua, otoritas Alkitab bersifat normatif. Lagipula, adalah mustahil untuk melepaskan otoritas Alkitab dari otoritas Allah. ${ }^{86}$

\section{Penutup}

Uraian tentang fakta dan problematika kesalahan tekstual menunjukkan beberapa contoh kesalahan dalam Alkitab. Para oponen otoritas Alkitab melihat bahwa berbagai kesalahan tersebut mengindikasikan ketidakpastian makna teks yang berdampak pada ketiadaan otoritas absolut Alkitab. Pandangan ini berbeda dengan pendapat para proponen yang menampik eksistensi kesalahan tekstual (Khoo) dan mempertanyakan prasuposisi teologis kritik teks (Ferguson). Pihak proponen juga menyatakan bahwa kesalahan tekstual umumnya bersifat tidak signifikan (Wallace) dan dapat dilengkapi (dijelaskan) oleh bagian Alkitab lainnya (Frame).

bagian ini, komitmen mereka kepada pandangan injili tentang otoritas Alkitab perlu dipertanyakan.

\footnotetext{
${ }^{86}$ Sebagaimana yang Frame jelaskan bahwa "divine authorship is the ultimate reason why Scripture is authoritative. Its authority is absolute because God's authority is absolute, and Scripture is his personal word to us" (The Doctrine of the Word of God, 165).
}

Prasuposisi yang disarankan oleh Ferguson dan Frame adalah baik dan vital, namun memiliki kesulitan karena tidak memberikan common ground (titik temu) terhadap dialektika akademis bagi pihak yang berseberangan dengan prasuposisi mereka. Penulis juga tidak sependapat dengan sikap Khoo yang menentang kritik teks. Motivasi yang baik dari Khoo layak untuk dipuji, namun sikapnya yang menutup mata terhadap berbagai kesalahan tekstual dengan cara menolak kritik teks adalah sikap yang tidak bertanggung jawab. Ini merupakan kelemahan pandangan Khoo. Prasuposisi alkitabiah yang sehat perlu menguasai kritik teks yang teliti sehingga gereja mendapatkan manfaat maksimal dari penelitian terhadap kekayaan firman Tuhan.

Melalui diskusi teologis yang dilakukan, penulis mendapati bahwa terlepas dari berbagai kesalahan tekstual, Alkitab tetap memiliki kepastian makna teks. Ini dikarenakan (1) perubahan teks tidak berdampak signifikan pada makna teks, (2) jumlah varian yang banyak memungkinkan adanya ketersalingan dalam verifikasi makna, dan (3) ketiadaan kemungkinan konspirasi menunjukkan adanya nilai dan rujukan historis di dalam teks. Kepastian makna teks ini memiliki implikasi kepastian otoritas dalam Alkitab. Akhirnya, penulis menyimpulkan bahwa kesalahan tekstual dalam Alkitab tidak meniadakan otoritas Alkitab. 


\section{Daftar Kepustakaan}

Aland, Kurt, Barbara Aland, Johannes Karavidopoulos, dan C. M. Martini, ed. Nestle-Aland: Novum Testamentum Graece. Ed ke-27. Stuttgart: Bibelgesellschaft, 2006.

Beale, Gregory K. "Can the Bible Completely Inspered by God and Yet Still Contain Errors? A Response to Some Recent 'Evangelical' Proposals.” Westminster Theological Journal 73, no. 1 (Spring 2011): 1-22.

Brotzman, Ellis. Old Testament Textual Criticism: A Practical Introduction. Grand Rapids: Baker, 2006.

Collins, John J. The Bible after Babel. Grand Rapids: Eerdmans, 2005.

Ehrman, Bart D. Misquoting Jesus: The Story behind Who Changed the Bible and Why. New York: HarperOne, 2007.

Elliger, Karl dan Wilhelm Rudolph, ed. Biblia Hebraica Stuttgartensia. Stuttgart: Deutsche Bibelgesellschaft, 1987.

Fee, Gordon D. New Testament Exegesis. Louisville: Westminster John Knox, 2002.

Ferguson, Paul. "The Battle over Presupposition on the Textual Issue.” The Burning Bush 16, no. 1 (January 2010): 22-45.

Frame, John M. The Doctrine of the Word of God. Phillipsburg: P\&R, 2010.

Geisler, Norman L. dan William E. Nix. A General Introduction to the Bible. Chicago: Moody, 1986.

Geisler, Norman L. dan Thomas A. Howe. Making Sense of Bible Difficulties. Grand Rapids: Baker, 2009.

Ginsburg, Christian D. Introduction to the Massoretico-Critical Edition of the Hebrew Bible. New York: Ktav, 1966.

Khoo, Jeffrey. “A Plea for A Perfect Bible.” The Burning Bush 9, no. 1 (January 2003): 1-15.

. "Can Verbal Plenary Inspiration Do Without Verbal Plenary Preservation? The Achilles Heel of Princeton Bibliology." The Burning Bush 13, no. 1 (January 2007): 25-43.

. "Inspiration, Preservation, and Translations: In Search of the Biblical Identity of the Bible - Presbyterian Church.” The Burning Bush 13, no. 1 (January 2007): 1-24.

. "John Owen on the Perfect Bible.” The Burning Bush 10, no. 2 (July 2004): 74-85.

. "Lost Word in Our Bible?” The Burning Bush 13, no. 1 (January 2007): 44-49.

McDonald, Lee M. "Where Lies Authority? A Discussion of Books, Texts, and Translations." Dalam Exploring the Origins of the Bible: Canon Formation in Historical, Literary, and Theological Perspective, diedit oleh Craig A. Evans dan Emanuel Tov, 203-253. Grand Rapids: Baker Academic, 2008.

Metzger, Bruce M. dan Bart D. Ehrman. The Text of the New Testament: Its Transmission, Corruption, and Restoration. Ed. ke-4. Oxford: Oxford University, 2005.

Morris, Leon. The Gospel According to Matthew. PNTC. Grand Rapids: Eerdmans, 1992. 
Nolland, John. The Gospel According to Matthew. NIGTC. Grand Rapids: Eerdmans, 2005.

Proctor, Mark A. "The 'Western’ Text of Mark 1:41: A Case for the Angry Jesus." Ph.D. diss., Baylor University, 1999.

Sakenfeld, Katharine D. “Whose Text Is It?” Journal of Biblical Literature 127, no. 1 (Spring 2008): 5-18.

Smith, Christian. The Bible Made Impossible: Why Biblicalism Is Not a Truly Evangelical Reading of Scripture. Grand Rapids: Brazos, 2012.

Sproul, Robert C. Essential Truth of the Christian Faith. Illinois: Tyndale, 1992.

Van Til, Cornelius. An Introduction to Systematic Theology. Diedit oleh William Edgar; Phillipsburg: P\&R, 2007.

Wallace, Daniel B. "Lost in Transmission: How Badly Did the Scribes Corrupt the New Testament Text?" Dalam Revisiting the Corruption of the New Testament: Manuscript, Patristic, and Apocryphal Evidence, diedit oleh Daniel B. Wallace, 19-55. Grand Rapids: Kregel, 2011.

. "The Gospel According to Bart: A Review Article of Misquoting Jesus by Bart Ehrman." Journal of the Evangelical Theological Society 49, no. 2 (June 2006): 327-349.

Wilkins, Michael J. Matthew. NIVAC. Grand Rapids: Zondervan, 2004.

Wright, Nicholas T. "How Can the Bible Be Authoritative?" Vox Evangelica 21 (1991): 7-32, http://ntwrightpage.com/Wright_Bible_Authoritative.htm. Diakses pada 14 Oktober 2014.

. The Last Word: Scripture and the Authority of God-Getting beyond the Bible Wars. New York: HarperCollins, 2005. 